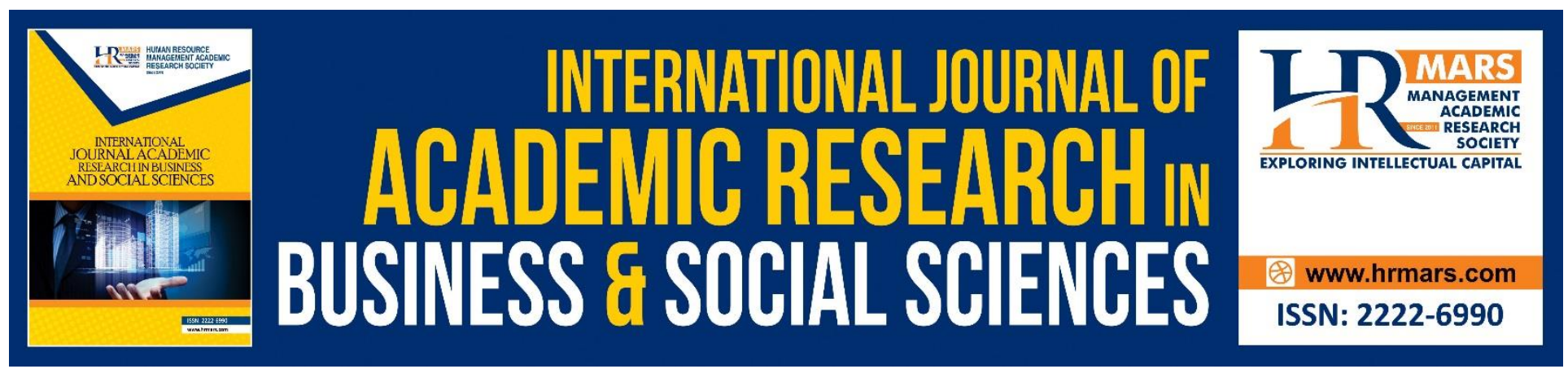

\title{
The Quranic Depiction of Pharaoh the Sinner: Textual Analysis
}

\section{Suzana Sulaiman \& Noor Eliza Abdul Rahman}

To Link this Article: http://dx.doi.org/10.6007/IJARBSS/v8-i12/5348

DOI: $10.6007 /$ IJARBSS/v8-i12/5348

Received: 11 Nov 2018, Revised: 27 Dec 2018, Accepted: 30 Dec 2018

Published Online: 06 Jan 2019

In-Text Citation: (Sulaiman \& Rahman, 2018)

To Cite this Article: Sulaiman, S., \& Rahman, N. E. A. (2018). The Quranic Depiction of Pharaoh the Sinner: Textual Analysis. International Journal of Academic Research in Business and Social Sciences, 8(12), 1851-1860.

Copyright: (C) 2018 The Author(s)

Published by Human Resource Management Academic Research Society (www.hrmars.com)

This article is published under the Creative Commons Attribution (CC BY 4.0) license. Anyone may reproduce, distribute, translate and create derivative works of this article (for both commercial and non-commercial purposes), subject to full attribution to the original publication and authors. The full terms of this license may be seen

at: http://creativecommons.org/licences/by/4.0/legalcode

Vol. 8, No. 12, 2018, Pg. 1851 - 1860

http://hrmars.com/index.php/pages/detail/IJARBSS

JOURNAL HOMEPAGE

Full Terms \& Conditions of access and use can be found at http://hrmars.com/index.php/pages/detail/publication-ethics 


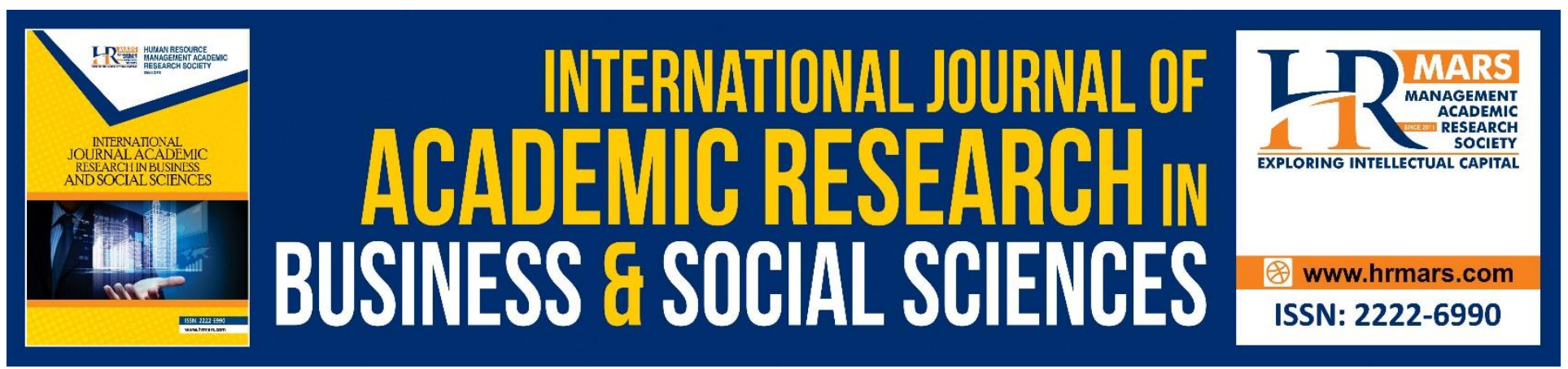

\title{
The Quranic Depiction of Pharaoh the Sinner: Textual Analysis
}

\author{
Suzana Sulaiman ${ }^{1} \&$ Noor Eliza Abdul Rahman ${ }^{2}$ \\ ${ }^{1}$ Faculty of Languages and Communication, Universiti Sultan Zainal Abidin \\ Email: suzana@unisza.edu.my \\ ${ }^{2}$ Faculty of Islamic Contemporary Studies, Universiti Sultan Zainal Abidin, Email: \\ nooreliza@unisza.edu.my
}

\begin{abstract}
Many scholars briefly analyzed some Quranic figures and focused primarily on particular Major Prophets, legendary figures and rebellious characters in their research. In this paper, the Quranic figure to be discussed is Pharaoh the notorious sinner. Interestingly, this study will illustrate how the Quran demonstrated the character of Pharaoh and his transgression from linguistic approach. However, it is not a purely linguistic study. The methodology of the study is to conduct a lexicographical method including semantic signals, describing it from narrative approach as well as it is blended exegetically. Therefore, some major Quranic exegetes such as tafsir al-Tabarī, al-Qurțubi and al-Zamakshari are being quoted. The samples are collected from fifteen different Quranic surahs connected to Pharaoh by using selected Quranic indexes and Quranic translation. As one of the Quranic depiction, the study will also imply the textual analysis; Problem-Solution Patterns introduced by Michael Hoey the linguist. The finding of the result is the Quran communicates its readers, admonishes them towards the transgression of Pharaoh as the main character, and the flow of the stories lies beautifully with the assistance of the supporting characters around Pharaoh throughout the Holy Quran, which is explicitly and implicitly portrayed.
\end{abstract}

Keywords: Quran, Pharaoh, Textual Analysis, Problem-Solution Patterns, Michael Hoey

\section{Introduction}

It is noticeable that there are loads of interest in various researches describing person and other humans around them, from such as the story of the companions of the cave, Mary's story during the birth of Jesus, the difference between the character of Moses and Abraham, Joseph's patience towards Zulaykha's tricks and womens' plotting (Quțb, S., 1983), Adam, Eve and Satan's rebellious character, major Prophets like Shu'ayb, David and Solomon, legendary figures like Dhul Qarnayn, Luqmān and Korah, (Sherif, 1985), the development of Moses's character and his relationship with Pharaoh, the Israelites, Jacob and Dhul Qarnayn (Wheeler, 2006), Moses and his connection with Aaron, and the Samaritan (Albayrak, 2001), and the manifestation of Jesus in the Quran (Parrinder, 
1965). However, this study attempts to explore the character of Pharaoh from Quranic perspectives, and of course in different angles of views.

In the Quranic parables, different groups of humans who are representative samples of a specific human character are encountered. Some characters, for instance, symbolize evil such as Pharaoh, while Asiah the wife of Pharaoh symbolizes a good wife whose faith was contradicty different between her and husband. Sherif (1985) states that Pharaoh is 'an archetype for autocracy'. Firestone (2004) describes him as the 'symbol of arrogance and evil'. For Ibn Taimiyyah (1998), Pharaoh represents the haughtiest creature against God owing to his polytheism.

\section{Methodology}

Prior to identifying the Quranic text concerning Pharaoh and his charactersitics, numerous specimens of ayahs are considered. These samples are first specified at the initial phase of selection through $A$ Guide to the Contents of the Qur'an by Faruq Sherif (1985). The samples then collected from fifteen different Quranic surahs connected to Pharaoh by using selected Quranic indexes by ${ }^{\mathrm{C}} \mathrm{Abd}$ al-Baqi (2007) and Hanna E. Kassis (c1983). Accordingly, the study also quoted from Quranic translation based on The Quran: Saheeh International: Arabic text with Corresponding English Meanings (1997). Those samples are supported by the most established classical tradition of exegetes by al-Tabari (1960), al-Qurtubi's exegesis (2003) as a linguistic and jurisprudential exegesis and al-Zamakhshari's exegesis (1998) for the purpose of its rehetorical and grammatical aspects of the Quran. In addition to these approaches, the study attempts to analyse these samples by proposing the Problem-Solution Patterns introduced by Michael Hoey, since it rarely been implied to the Quran from the perspective of textual analysis.

\section{Analysis}

\section{Pharaoh from the perspective of first-person narrative}

To demonstrate the evil side of Pharaoh, the study suggests how Quran personifies Pharaoh's character as follows: The samples for this section are derived from three Quranic surah. All are surah makkiyah.

1. In Surah al-Naziat, Pharaoh claimed himself as the most exalted lord, affirmed by the word (I am).

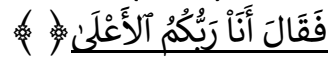

(Al-Naziat 79: 24)

2. In Surah al-Zukhruf, Pharaoh proclaimed among his people, saying: "O my people! does not the kingdom of Egypt belong to me, and these rivers flowing beneath me; then do you not see?

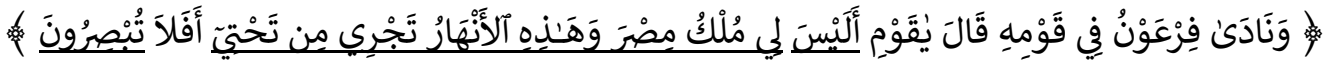

(Al-Zukhruf 43: 51) 
INTERNATIONAL JOURNAL OF ACADEMIC RESEARCH IN BUSINESS AND SOCIAL SCIENCES

Vol. 8, No. 12, Dec, 2018, E-ISSN: $2222-6990$ C 2018 HRMARS

3. In al-Syuara', Pharaoh threaten to whoever take a god other than him, he will surely place them among those imprisoned.'

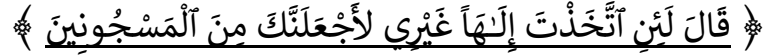

(Al-Syuara' 26: 29)

4. In al-Syuara', [Pharaoh] said, 'You believed Moses before I gave you permission. Indeed, he is your leader who has taught you magic, but you are going to know. I will surely cut off your hands and your feet on opposite sides, and I will surely crucify you all.'

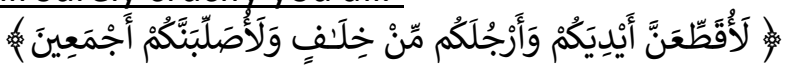

(Al-Syuara' 26: 49)

\section{Pharaoh from the perspective of third person narrative}

The samples for this section are derived from six Quranic surah: an-Naziat, Toha, al-Dukhhan, alMukmin, Ibrahim \& al-Baqarah. All six are surah Makkiyah except al-Baqarah.

1. Surah al-Naziat, 'Go to Pharaoh. Indeed, he has transgressed.'

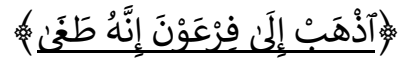

(Al-Naziat 79: 17)

2. Go to Pharaoh. Indeed, he has transgressed.

(Toha 20: 24)

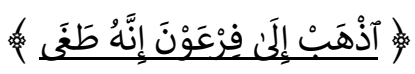

3. Go, both of you, to Pharaoh. Indeed, he has transgressed.

(Toha 20: 43)

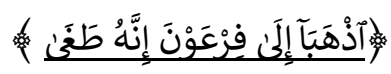

Exegetically, we have found the expression (țaghā - to oppress, to transgress) occurs in the first revelation of the Quran, i.e., Q96, to highlight the notion of oppression, tyranny, transgression, and feeling superior to others as a major sin in Islam. This notion is presented repeatedly in the Quranic parable of Pharaoh, as in Q79:17, Q20:24, and Q20:43.

4. From Pharaoh. Indeed, he was a haughty one among the transgressors.

(Al-Dukhan 44: 31)

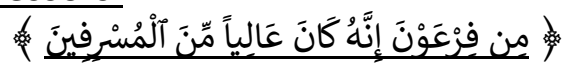

5. But Moses said, 'Indeed, I have sought refuge in my Lord and your Lord from every arrogant one who does not believe in the Day of Account.'

(Al-Mukmin 40: 27)

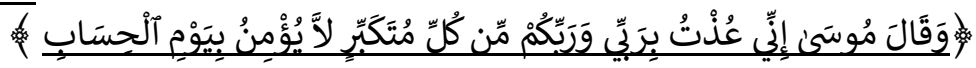

Al-Zamaksharī (1998) has included Pharaoh indirectly among (al-jabābirah - the arch-tyrants). Therefore, Pharaoh is the third person meant in the dialogue.

The antoganist and the protoganist characters in one sample presentation

In this section, the study proposes how the Quran make comparison between the antoganist and the protoganist characters in one single ayah from the view of the Quranic similitude. Asiah or more familiar with the title "the wife of Pharaoh" is the example of believers. She is being compared with 
the wife of Noah and the wife of Lot in Quran 66:10. Consecutively, Asiah is praised obviously in Quran 66:11 [And Allah presents an example of those who believed: the wife of Pharaoh, when she said, "My Lord, build for me near You a house in Paradise and save me from Pharaoh and his deeds and save me from the wrongdoing people."]. It was wonderfully presented in Quranic similitude as Figure 1 below:

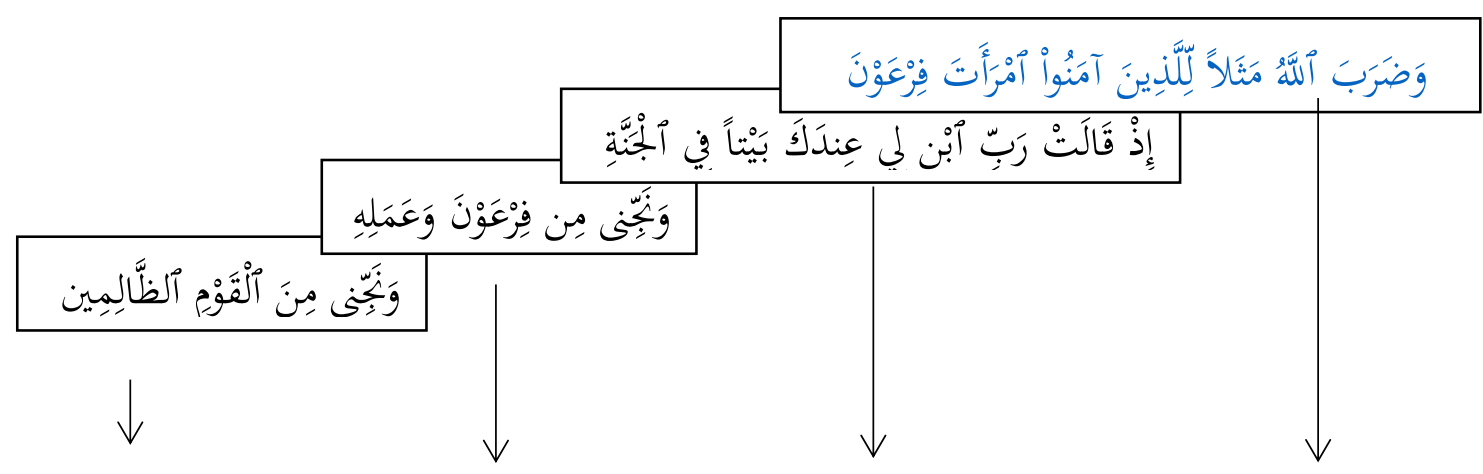

Bani Israel Pharaoh Pharaoh's wife God's praise and approval

Figure 1: the wife of Pharaoh in Quranic similitude

In the view of al-Zarkashī (1988), a person's name, i.e., identity is not mentioned 'in order to shield his/her name from being recognized to avoid humiliatiation and reference to negative feedback on/him/her. Some Quranic characters are referred to in the Quran without their names, and that their character is mirrored through other well-known proper names, such as the wife of Prophet Lüt and the wife of Prophet Nūḥ. Thus, we find (أمرأة لوط) meaning 'the wife of Lot'. Grammatically, however, the word (لوط) (Lūț) does not function as the adjective of the noun (أمرأة - wife) although the expression (أمرأة لوط) is a construct noun phrase (ị̂āfah).

According to Bakr (1984), the function of (al-iḍāfah) is to build a link of connection (al-ittișāl) between (al-muḍāf) and (al-muḍāf ilayhi). Thus, I believe that this connection may express the notion of 'belonging to, or possession' by the denotative meaning of (اللام- for; belong to) between (أمرأة- wife) and (لوط - Lūț). For Khaleel Mohammed (2006), however, the reference of females to their male relationship is reflected by the role of the male as their protector. However, there are other Quranic women whose citation is not explicitly mentioned not due to being concealed for fear of shame but rather because of our familiarity with the person referred to in the context of the Quranic parable. Eve, for instance, is not explicitly highlighted in the parable since she is known as 'Adam's counterpart and complement' (Schőck, 2001). In Quran 2:35 [And We said, 'O Adam, dwell, you and your wife, in Paradise and eat there from in [ease and] abundance from wherever you will'], al- Zarkashī (1988) assert that the term (وزوجك - and your wife) refers to (ḥawwā' - Eve) as the first human origin of woman. 
INTERNATIONAL JOURNAL OF ACADEMIC RESEARCH IN BUSINESS AND SOCIAL SCIENCES

Vol. 8, No. 12, Dec, 2018, E-ISSN: 2222-6990 @ 2018 HRMARS

Another comparison between the antoganist and the protoganist characters in one single ayah encountered in Quranic parable, Q28:9 [And the [wife of Pharaoh said, "[He will be] a comfort of the eye for me and for you. Do not kill him; perhaps he may benefit us, or we may adopt him as a son." And they perceived not], we notice four characters introduced in one short āyah that can be explained as Q28:9 in Figure 2 below:

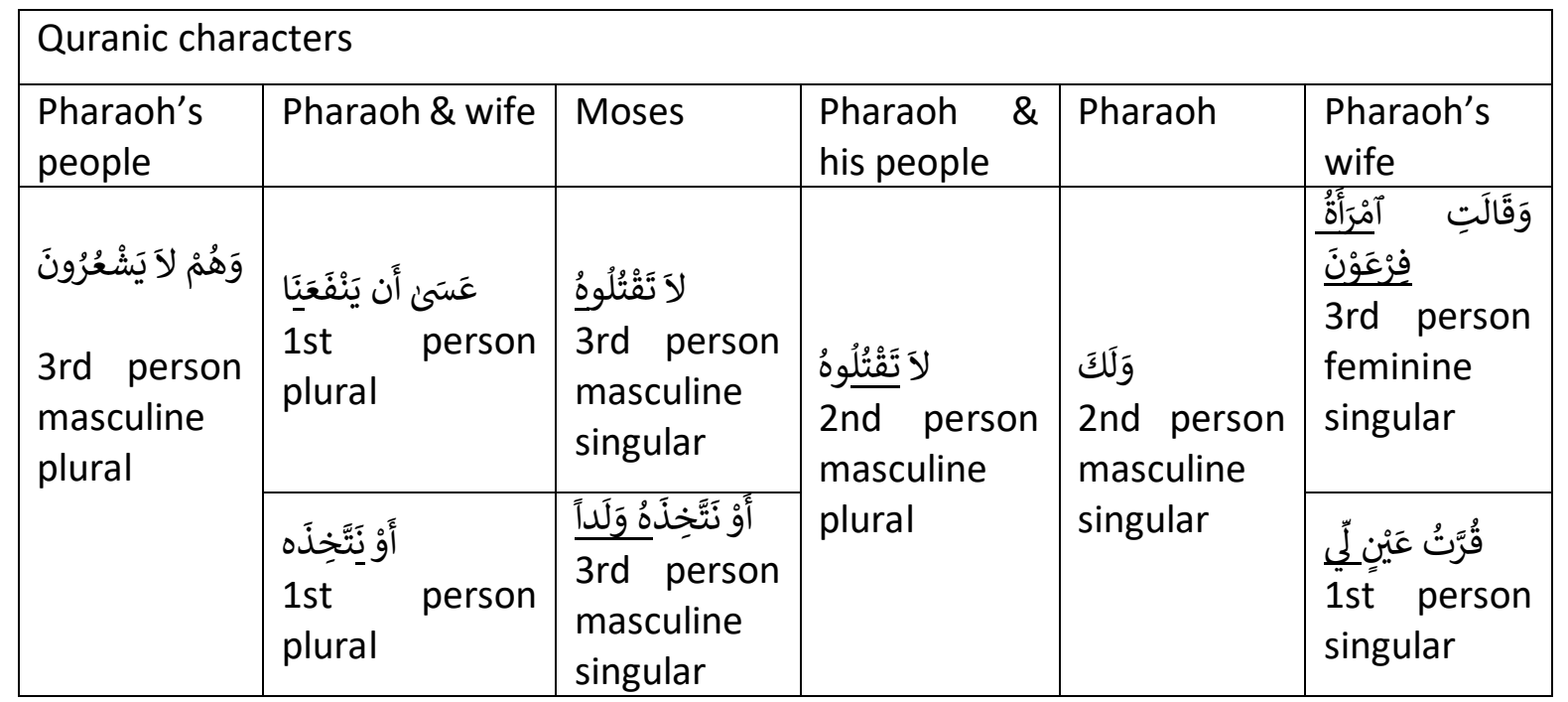

Figure 2: The antoganist and the protoganist characters in one single ayah, Q28:9

Regarding the noun (وَََ) - walad - little boy in the previous example, it involves Moses where the main character is the wife of Pharaoh when she pleads with Pharaoh for Moses' life. The word (وََلَ) here refers to Moses.

\section{The transgression of Pharaoh by the manifestation of others}

The Quran provides other Quranic figures related to Pharaoh, to explain his dark side of evil. In terms of the group of people encountered in Quranic parables, the group can be listed in five expressions, such as (așhāb - companions), (āl - family), (ahl - family), (mala' - people) and (qawm - nation, people). However, only 3 expressions involve Pharaoh, and the other two falls out of the concern of this paper. The expression is figured out as follows:

1. (qawm - nation, people).

The Quran most preferred word for people is (qawm). Normally, it is treated with Prophets' tribe like Moses, Noah, Șālih and etc. in punishment stories. However, the noun (mala') has also occurred in other Quranic parables other than that of Pharaoh, such as Q7:88 which refer to Prophet Shu'ayb, and Q11:38 which refer to Prophet Noah.

\section{2. (mala' - people)}

The noun (mala') usually refers to Pharaoh's people to whom the message of monotheism is sent, [ilā fircawna wa mala'ihī], whether by Moses alone as in Q7:103, Q11:97, Q43:46, or along with Aaron Q10:75. Arberry (1998) translates (mala'ihī) in these āyahs as 'Pharaoh's folk'. I believe that the seven 
INTERNATIONAL JOURNAL OF ACADEMIC RESEARCH IN BUSINESS AND SOCIAL SCIENCES

Vol. 8, No. 12, Dec, 2018, E-ISSN: $2222-6990$ C 2018 HRMARS

instances of (mala') [(mala'ahu) in Q10:88, (mala'ihi) in Q7:103, Q10:75, Q11:97, Q23:46, Q28:32 and Q43:46] that occur with Pharaoh in the Quran have the rhetorical function of sarcatism towards Pharaoh's tyranny and oppression and his claim that he is 'God'.

\section{3. (āl - family)}

According to al-Tabarī (1992), the word (āl) in the Quran is derived from (ahl) where the second letter (hä') is assimilated into the initial letter (hamzah). The employment of (āl) in the Quran is primarily

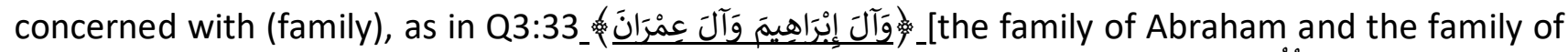

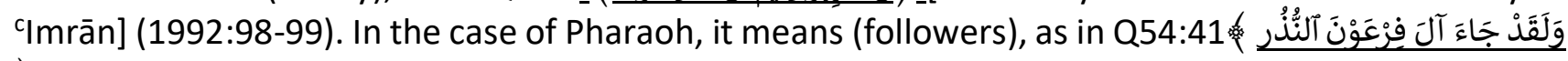
IAnd there certainly came to the people of Pharaoh warning]. Moreover, Aisha Bewley when translating al-Qurțubī's idea claims that the people (āl) of Pharaoh refers to anybody 'who follow his din in his time and at all times, whether related to him or not' (al-Qurțubī, 2003).

Example 1:

The translation:

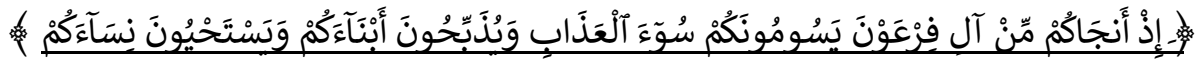

'Remember the favor of Allah upon you when He saved you from the people of Pharaoh, who were afflicting you with the worst torment and were slaughtering your [newborn] sons and keeping your females alive.

(Ibrahim 14: 6)

Example 2:

The translation:

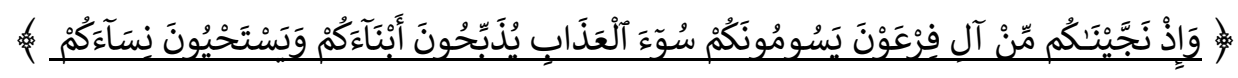

And [recall] when We saved your forefathers from the people of Pharaoh, who afflicted you with the worst torment, slaughtering your [newborn] sons and keeping your females alive].

(Al-Baqarah 2: 49)

The tyranny of Pharaoh is described by the sequence of three present tense verbs (al-ficl al-muḍāric

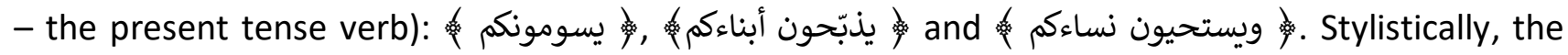
function of repeating the present tense verb in one sentence is to signify the fact that a given action has become a routine practiced repeatedly. Also, it is a reminder to the People of Isrä'il (the Israelites) of how God saved them from the tyranny and oppression of Pharaoh (Hindāwī, 2008). The relationship to the past time (al-māội) is demonstrated by using the word (إذ) initially (al-Shādhilī,

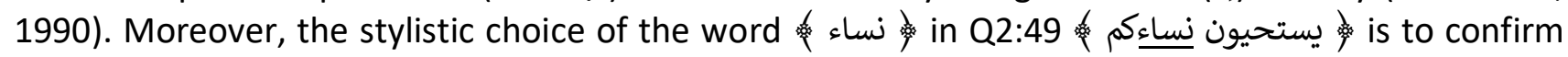
and highlight Pharaoh's transgression, because (النساء) is the plural of (النسوة); it also connotes the female gender, wives and even daughters ('Umar, 2001).

\section{Problem-Solution Pattern}

The beauty of Quranic communication lies on how the story should end as presented in the parable of Moses in Q26:10-15. The sample is elaborated according to Problem Solution Pattern by Michael Hoey $(1983 ; 2001)$ will be applied in this analysis. Hoey gives four points in the problem solving pattern: 
(i) situation, which interprets the participants of such circumstances bounded by specific time frame and location,

(ii) problem, which spell out the complication and obstacles arisen between participants,

(iii) solution, where such suggestion is provided to resolve the remarkable problem, and

(iv) evaluation, where an assessment of the solution is put forward as a post-mortem of the issue.

There is a form of structure called 'multi-layering', or in Hoey's recent work (1983), he uses the term 'recycling' (2001). The problem-solution pattern has two possibilities: negative evaluation, or positive evaluation. The important point is a negative evaluation which is a signal of another problem. The next structure below is Figure 3 that represents Hoey's concept of multi-layering or recycling:

\section{Situation}

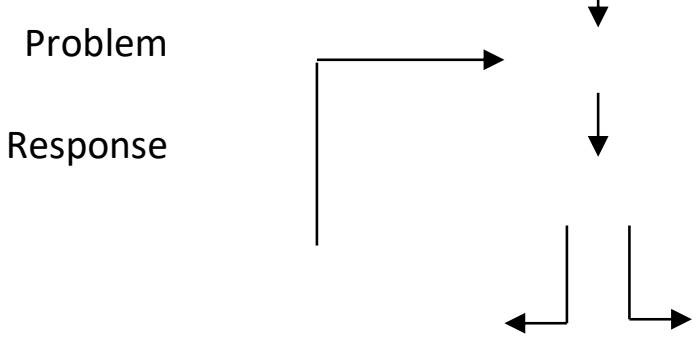

$$
\begin{array}{rr}
\text { Negative Evaluation } & \text { Positive Evaluation } \\
\text { and/or Result } & \text { and/or Result (end of discourse) }
\end{array}
$$

\begin{tabular}{|c|c|}
\hline $\begin{array}{l}\text { Question arisen: Who are the wrongdoing } \\
\text { people? The Quran responds: }\end{array}$ & The Problem-Solution pattern \\
\hline 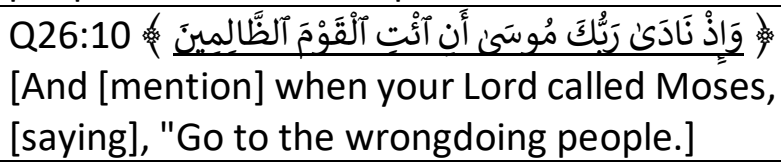 & Situation \\
\hline 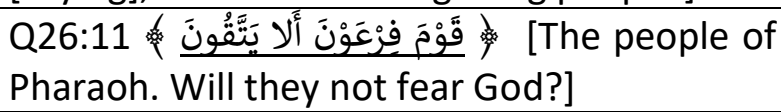 & Problem \\
\hline 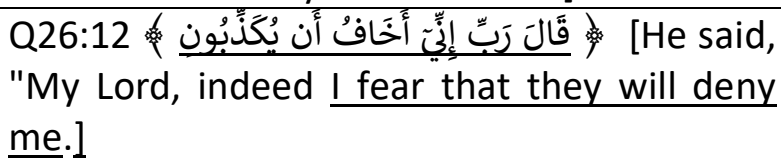 & Response 1 [Moses] \\
\hline 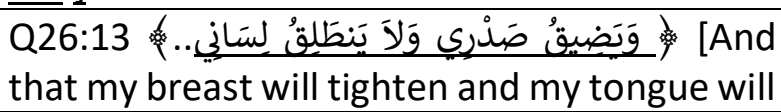 & Evaluation \\
\hline
\end{tabular}

Figure 3 Multi-layering problem-solution patterns adapted from Hoey (2001)

To demonstrate the Problem-Solution pattern by Hoey, we chose the parable of Moses and his confrontation against Pharaoh in Q26, which can be delivered as following table: 
INTERNATIONAL JOURNAL OF ACADEMIC RESEARCH IN BUSINESS AND SOCIAL SCIENCES

Vol. 8, No. 12, Dec, 2018, E-ISSN: 2222-6990 @ 2018 HRMARS

\begin{tabular}{|c|c|}
\hline 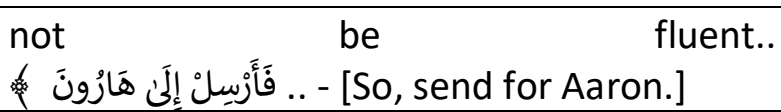 & \\
\hline 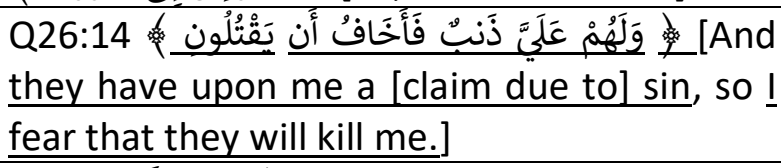 & Problem \\
\hline 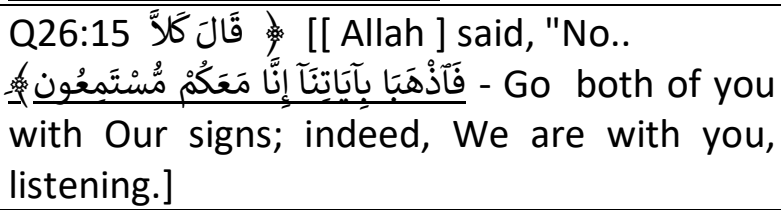 & Solution + Response 2 [Allāh] + Evaluation \\
\hline
\end{tabular}

Figure 3: Parable of Moses in Problem Solution Pattern

Through Problem Solution Pattern by Michael Hoey, it provides us the evidence of how the flow and plot of Pharaoh's stories lies in the beauty presentation of the Holy Quran.

\section{Conclusion}

To sum up, blended in linguistic, lexical and exegetical approach, Pharaoh was textually and semantically depicted by the Holy Quran through the assistance of the supporting characters around him, whom were explicitly and implicitly portrayed. Obviously, the Holy Quran communicates its readers and admonishes them towards the transgression of Pharaoh, the notorious sinner ever lived.

\section{References}

'Abd al-Bāqī, M. (2007). 'al-Mu'jam al-Mufahras li-Alfāz al-Qur'an al-Karīm wifqa nuzūl alkalimah (5th ed.). Beirut: Dār al-Ma'rifah.

Albayrak, I. (2001). The Qur'anic narratives of the Golden Calf episode. Journal Of Qur'Anic Studies, 3(1), 60-67.

Arberry, A. (1998). The Koran interpreted. Oxford: Oxford University Press, p.555.

Bakr, Y. (1984). Nușūṣ fĩ al-Naḥw al-'Arabī: Min al-Qarn al-Sādis ilā al-Thāmin (p. 259). Beirut: Dār alNahḍah al-'Arabiyyah.

Firestone, R. (2004). Pharaoh. In: Encyclopaedia of the Qur'ān. (Vol 4, pp. 66-68). Brill: Leiden

Al-Hindāwī. (2008). al-l'jāz al-Ṣarfĩ fĩ al-Qur'ān al-Karīm: Dirāsah Naẓariyyah Tațbīqiyyah: al-Tawzīf al-Balāghī li-Ṣighat al-Kalimah (pp. 226-227). 'Ammān: Jidār al-Kitāb al-'Ālamī.

Hoey, M. (1983). On the surface of discourse. London: Allen \& Unwin, pp.31-61.

Hoey, M. (2001). Textual Interaction: An Introduction to Written Discourse Analysis.. London: Routledge, pp.123-141. 
INTERNATIONAL JOURNAL OF ACADEMIC RESEARCH IN BUSINESS AND SOCIAL SCIENCES

Vol. 8, No. 12, Dec, 2018, E-ISSN: $2222-6990$ C 2018 HRMARS

Ibn Taimiyyah, A. (1998). Majmū'at al-Fatāwā (2nd ed., p. 117). al-Manșūrah: Dār al-Wafā'.

Kassis, H. (1983). A Concordance of the Qur'an. Berkeley: University of California Press.

Mohammed, K. (2006). Sex, sexuality and the family. In The Blackwell Companion to the Qur'ān (pp. 298-307). Malden, MA: Blackwell Pub.

Parrinder, G. (1965). Jesus in the Qur'ān. London: Faber.

Al-Qurțubī, M. (2003). al-Jāmi' li-Aḥkām al-Qur'ān. English Tafsir al-Qurtubi: Classical Commentary of the Holy Qur'an (p. 247). London: Dar al-Taqwa.

Quțb, S. (1983). al-Tașwīr al-Fannī fĩ al-Qur'ān (8th ed., pp. 190-209.). Beirut and Cairo: Dār al-Shurūq.

Saheeh International. (1997). The Quran: Arabic text with Corresponding English Meanings. Almunatada Alislami.

Shādhilī, A. (1990). al-'Anāsir al-Asāsiyyah lil-Murakkab al-Fi'lī wa-Anmātihā min Khilāl al-Qur'ān alKarīm: Dirāsah Taḥlīliyyah Tațbīqiyyah (p. 26). Alexandria: Dār al-Ma'rifah al-Jāmi'iyyah.

Schőck, C. (2001). Adam and Eve. In: Encyclopaedia of the Qur'ān. Brill: Leiden, pp.22-26.

Sherif, F. (1985). A Guide to the Contents of the Qur'an. London: Ithaca Press, pp.46-68.

Al-Tabarī, Ibn Jarīr. (1992). Daqā'iq Lughat al-Qur'ān fí Tafsīr Ibn Jarīr al-Tabarī (pp. 98-99.). Beirut: 'Ālam al-Kutub.

Umar, A. (2001). Ta'addud al-Jumū' lil-Mufrad al-Wāhid fĩ al-Qur'ān. Journal Of Qur'Anic Studies, 3(2), 132-170.

Wheeler, B. (2006). Moses. In The Blackwell Companion to the Qur'ān (pp. 248-265). MA Malden: Blackwell.

Al-Zamakhsharī. (1998). al-Kashshāf (Vol. 5, pp. 341-342). al-Riyāọ: Maktabat al-'Ubaikān.

Al-Zarkashī, A. (1988). al-Burhān fí Ulūm al-Qur'ān (Vol. 1, pp. 204-207). Beirut: Dār al-Kutub alIlmiyyah. 